\title{
Innsats over mange år gir resultater: positiv evaluering av undervisningsprogrammet Vivat
}

\author{
Ved Hans Lander og Dag Willy Tallaksen
}

vivat

\begin{abstract}
Siden 1998 har Vivat med kurset “Førstehjelp ved selvmordsfare” vært en del av den statlige Handlingsplan mot selvmord, og flere enn 12000 personer har deltatt på kurset. Sosial- og helsedirektoratet, som finansierer Vivat, ønsket en ny og omfattende evaluering av Vivat for å få innsikt i om deltakernes kompetanse og evne til å intervenere ved akutt selvmordsfare varer over tid, og/eller om den medfører kompetanseheving på arbeidsplassen. Høsten 2006 og våren 2007 ble evalueringen gjennomført, og den ga positive resultater.
\end{abstract}

H ittil har mer enn 12000 personer del tatt på førstehjel pskurset, og det finnes i dag 120 aktive kursledere. Vivat utdanner, i tillegg til kursledere, også veiledere som et ledd i sin interne kvalitetssikring.

Sosial- og helsedirektoratet har en stund ønsket en evaluering av Vivat. Slike evalueringer er forskningsmessig svært utfordrende. Derfor var det internt i Vivat knyttet spent forventning til hva som ville bli resultatet av dette. I 2006 ble oppdraget lagt ut på anbud. Rambø|l M anagement fikk oppdraget, og høsten 2006 og våren 2007 ble evalueringen gjennomført.

Evalueringsrapporten ble lagt fram i mars 2007.

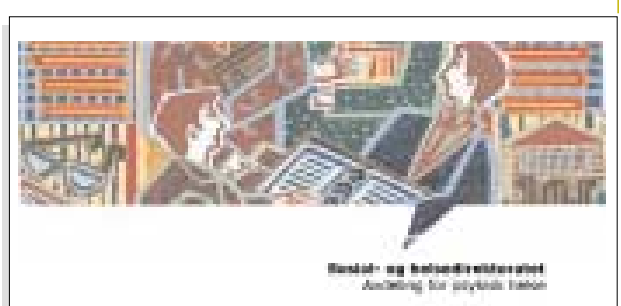

Evaluering av undervisningsprogrammet Vivat

\section{ститाँ}

Kan lastes ned fra www.unn.no/vivat

- D okumentarkiv (i menyen t.v.)

Dette er den første selvstendige evalueringen av kurset Førstehjelp ved selvmordsfare. Det finnes en begrenset evaluering fra 2000 som er en del av A genda $U$ tredning og $U$ tvikling sin evaluering av $\mathrm{H}$ andlingsplan mot selvmord. Sosialog helsedirektoratet satte rammene for den nye evalueringen til å omfatte følgende temaer: programmets organisering og forankring, metode, innhold og omfang, samt effekt. Evalueringen er utført ved hjelp av en rekke intervjuer med kursdeltakere, kursledere og veiledere/an satte i V ivat. U ndersøkelsen baserer seg også på innsamlede spørreskjemaer fra 249 kursdeltakere og 36 kursledere. R ambøll M anagement peker på at det var vanskelig å få tilstrekkelig respons på denne undersøkelsen, særlig blant kursdeltakere. Dette tilskrives i stor grad mangel fulle opplysninger om kursdeltakernes tel efonnummer, arbeidssted og adresser. Å rsaken til dette var en kombinasjon av mangelfulle registre og bytte av arbeidssted.

Her følger en sammenfatning av R ambøll $M$ an agements vurderinger:

\section{Organisering og forankring}

Vivat vurderes som både kostnadseffektivt og med et godt forankret nettverk av lokal ekspertise og faglig støtte. Tilknytningen til de regionale ressurssentre om vold, traumatisk stress og selvmordsforebygging (RVTS) ansees som hensiktsmessig. Videre påpekes det at Vivat har lykkes med å rekruttere deltakere fra rel evante fagmiljøer og arbeidsplasser. H er pekes også på at enkelte grupper er underrepresentert og at den geografiske spredningen ikke er helt tilfredsstillende. $\mathrm{N}$ oe av dette kan tilskrives manglende ressurser. En konsekvens er at informasj onsmateriell f. eks i form av brosjyrer etc. oppleves som utdatert. Sør- og M idt-N orge er fortsatt ikke godt nok dekket med tanke på kursdeltakere og kursledere. D ette kan i følge R ambøll ha sammenheng med helseforetakenes manglende organisering og/ eller vektl egging av sel vmordsforebyggende sentre i disse områder. Vivats kontakt med LivingW orks Education beskrives som en fornuftig form for kvalitetssikring med mulighet for påvirkning begge veier. Den internasjonale revisjonen i 2004 beskrives som en positiv utvikling.
Landsdekkende kurs:

Førstehjelp ved selvmordsfare

Førstehjelp ved selvmordsfare er et intensivt todagers kurs. Det retter seg mot alle som i sitt virke møter selvmordsnære mennesker, og er et praktisk, tverrfaglig kurs hvor deltakerne lærer å tyde faresignaler og gripe inn i tilfelle akutt selvmordsfare. Målet er at deltakerne etter kurset skal være mer kompetente og tryggere i å intervenere i akutte selvmordskriser. På kurset lærer man å:

- Fange opp mennesker som kan være i selvmordsfare

- Stille direkte spørsmål om selvmordstanker

- Hjelpe personen i selvmordsfare til å snakke om det som er vanskelig

- Gjøre en enkel risikovurdering

- Lage og iverksette en plan med vedkommende, hvor målet er å berge livet

- Bruke nære ressurser i krisehjelp

Mer enn 12.000 personer har deltatt på Vivat-kurset i Norge siden starten i 1998 Det er på verdensbasis det mest brukte selvmordsforebyggende kurset. Kurset er godkjent av flere fagforeninger som tellende i forbindelse med fagspesialisering.

Vivat er forankret i Universitetssykehuset Nord-Norge HF (UNN), hvor det er tilknyttet Ressurssenteret om vold, traumatisk stress og selvmordsforebygging, Region Nord (RVTS Nord). Det finansieres av Sosial-og helsedirektoratet.

For mer informasjon kontakt: Vivat, Universitetssykehuset Nord-Norge HF Postboks 6124, 9291 Troms $\emptyset$

www.unn.no/vivat e-post:vivat@unn.no

V ivat synes å ha en sentral rolle innen det totale kompetansehevingstilbudet for selvmordsforebygging. Tilknytningen til U N N og RVTS N ord ansees som en god løsning. 


\section{Undervisningsprogrammets kursmodell}

R ambøll $M$ anagement har her lagt vekt på det som omtales som totrinnsprinsippet. Det vil si at kursdeltakere kan gå videre etter førstehjel pskurset og selv bli kursledere. Rapporten viser til at denne modellen stort sett fungerer etter sin hensikt, men man peker på at det blant kurslederne er en overvekt av psykiatriske sykepleiere. Dette er ikke i samsvar med målsettingen om tverrfaglighet. Det bør legges mer vekt på en bredere tverrfaglig rekruttering $\mathrm{i}$ framtiden, eventuelt må dette målet endres. $\mathrm{N}$ år det gjelder det frivillige aspektet i kurslederarbeidet, så sies det at dette ikke er noen barriere verken for å bli eller bli værende som kursleder. Kurslederne peker på at det krever mye forberedelse og at det er en påkjenning à arrangere kurs. For noen kursl edere er nok dette en grunn til at de ikke arrangerer flere kurs enn det som er minstekravet for å fortsette i Vivat. I rapporten trekkes likevel den slutning at kurslederne opplever arbeidsmengden som overkommelig. Rapporten omtaler ordningen med kvalitetssikring av kursene som god. Begrunnelsen for dette finnes $i$ at kurslederne stort sett er fornøyde med oppfølgingen fra veilederne. Det framheves også at kurslederne utviser stor grad av interesse og engasj ement.

\section{Innhold og omfang}

Det faglige innholdet er i henhold til kursets intensjon ifølge rapporten.

Kurslederne beskrives som kompetente, og de formidler stoffet på en tilfredsstillende måte. Kurset har en passende vanskelighetsgrad. Evalueringen viser at kursdel takerne føler seg tryggere og mer i stand til å handle i selvmordssituasjoner etter å ha deltatt på kurset. Rapporten viser til at kurset ikke er ment å utdanne deltakerne til å behandle selvmordstruede mennesker, noe det pekes på at kurset heller ikke gjør. Evalueringsrapporten peker pă at kursets tverrfaglighet er en styrke som gir mulighet for erfarings- og kunnskapsutveksling. Videre stilles det spørsmål ved om leger og psykologer heller bør benytte andre etter- og videreutdanningskurs. Vurderingen er at kurset bidrar til opplevd kompetanseheving blant deltakerne. Det kommer fram tilfredshet med det undervisningsmateriale og de pedagogiske metoder som anvendes. Rapporten peker på at det er bygget opp et behov for oppføl gingskurs.

\section{Effekt av kursdeltakelsen}

Vurderingen sier at kursdeltakelsen til en viss grad har varig effekt for deltakeren. Et vedlikeholdskurs med ferdighetstrening ville forsterke denne effekten. Kursdeltakelse fører til styrking av tverrfaglig samarbeid og nettverk. Dette forutsetter at nettverksbygging prioriteres på kurset. Det pekes imidlertid på at kompetansen er knyttet til egen ferdighetstrening og er vanskelig overførbar. Det vil si at det er vanskelig å se at kompetanseheving på systemnivå finner sted i særlig grad.

\section{Kommentar fra Vivats ledelse}

Vivats ledelse er glad for de positive tilbakemeldingene som R ambølls rapport gir. Det påpekes også svakheter og foreslås noen tiltak til forbedringer. Vivat ser dette som nyttig og tar det til etterretning. Det vil bli tatt med i diskusjoner i Vivats styringsgruppe og organisasjon om utforming av fremtidige strategiplaner. Vivat har planlagt allerede fra høsten 2007 à starte utprøving av et nytt vedlikeholdskurs for tidligere kursdeltakere, noe som er anbefalt i rapporten. På bakgrunn av Rambølls evalueringsrapport har Sosial- og helsedirektoratet nå gitt Vivat i oppdrag å utforme et forslag til plan for organisering og forankring av Vivat som en permanent virksomhet.

H ans $\mathbf{L}$ ander er leder for U ndervisningsprogrammet $\mathrm{V}$ ivat. $\mathrm{H}$ an er klinisk spesialist $\mathrm{i}$ psykiatrisk sykepleie, cand.mag., og har siden 2001 arbeidet med selvmordsforebygging innenfor de nasjonale tiltak mot selvmord.

D ag Willy Tallaksen er førstelektor ved $\mathrm{H} ø$ skolen i A kershus, avdeling for sykepl eierutdanning og teamleder i Vivat. Sammen med $\mathrm{H}$ ans Lander har han ansvar for utdanning av kursledere og kvalitetssikring av virksomheten.
Videreutdanning i selvmordsforebyggende arbeid

60 studiepoeng. 2 år - halv tid .

Søknadsfrist 15. oktober 2007.

Studiestart januar 2008.

Studiets målgruppe er helsepersonell og andre som i sitt daglige arbeid har, eller vil fă, ansvar for å møte, vurdere og behandle sel vmordsnære mennesker. U tdanningen er også beregnet på fagpersoner som skal bygge opp og drive ulike selvmordsforebyggende tiltak i helsesektoren eller på andre arenaer.

\section{$H$ va lærer du?}

Innholdsmessig vil det bli lagt vekt på en bred gjennomgang av temaer knyttet til forståelse av og holdninger til selvmordsatferd, risikofaktorer og planlegging og gjennomføring av ulike selvmordsforebyggende tiltak.

$U$ tdanningen gir kompetanse til å drive selvmordsforebyggende virksomhet både lokalt og regionalt i forhold til mennesker i alle aldre. Du får bedre grunnlag for å arbeide klinisk og forebyggende med selvmordsnære grupper. Du får erfaring med prosjektarbeid og planlegging, gjennomføring og evaluering av forebyggen de tiltak. Du făr kompetanse $\mathrm{i}$ å holde kurs, gi veiledning og yte mer effektiv bistand til brukerne av dine tjenester.

\section{Studieavgift}

Studieavgiftene er kr. 12000 pr. semester. I tillegg betales semesteravgift til U niversitetet i O slo (ca. kr. 500 pr. semester).

\section{O pptakskrav}

Det kreves bachelorgrad, cand. mag.-grad eller annen helse- og/eller sosialfaglig utdanning av minimum 3 års varighet, eller andre relevante utdanninger som i henhold til $\S 48 \mathrm{i}$ lov om universiteter og høgskoler er godkjent som jevngod med overnevnte grader eller utdanningsløp. I tillegg kreves minst 2 års relevant yrkespraksis. $M$ er informasjon og søknadsskjema finner du på våre hjemmesider: www.selvmord.no under U tdanning.

\section{For ytterligere informasjon og} søknadsskjema, kontakt:

Elin A nita Fadum/
H enning H errestad/
Trine Jensen
Seksjon for sel vmords-
forskning og -forebygging
Sognsvannsveien 21,
bygning 12, 03200 slo
Telefon: 22923473
Faks: 22923958

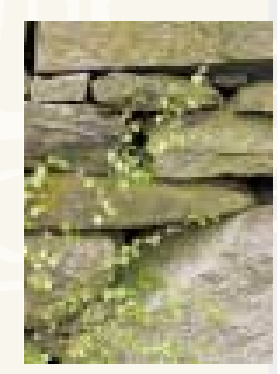

E-post: ssff-post@medisin.uio.no 